\title{
Business Demography in the 21st Century
}

\author{
Farhat Yusuf $\cdot$ David A. Swanson
}

Published online: 9 February 2010

(C) The Author(s) 2010. This article is published with open access at Springerlink.com

Murdock and Swanson (2008) observe that applied demography is evolving as the 21 st century unfolds and that data bases, substantive issues and methodological approaches seldom considered just a few years ago have become mainstream concerns in the field. Making up applied demography are two subsets: (1) public sector demography; and (2) business demography. Swanson and Pol (2008) argue that although estimation and projection are the heart and soul of both sectors and many methods and materials are common to both, it is useful to distinguish business demography from public sector demography because the unique, profit-oriented and often times proprietary nature of the work justifies separate consideration for business demography. Thus, in this special issue of Population Research and Policy Review, we are pleased to present an overview of the field of business demography at the dawn of the 21 st Century.

This overview is meant to largely complement examinations that have preceded it in the later part of the 20th century and in the earlier part of this one. Six books and three papers come to mind in this regard. The books include those by Rives and Serow (1984), Murdock and Ellis (1991), Kintner et al. (1994), Pol and Thomas (1997), Siegel (2002), and Murdock and Swanson (2008). The paper by Swanson et al. (1996) provides a useful overview of the development of applied demography and its two subsets, as do the papers by Smith and Morrison (2005) and Swanson and Pol (2008).

This attempt to provide a current overview of the increasing breadth and depth of the field of business demography has its roots in an international seminar sponsored

\footnotetext{
F. Yusuf $(\bowtie)$

Department of Business, Faculty of Business and Economics, Maquarie University, Sydney, NSW 2109, Australia

e-mail: Farhat.Yusuf@efs.mq.edu.au
}

\section{A. Swanson}

Department of Sociology, University of California Riverside, Riverside, CA 92521, USA

e-mail: dswanson@ucr.edu 
by the International Union for the Scientific Study of Population and organized by its Scientific Panel on Business Demography. The Panel consisted of Farhat Yusuf (Chair), Tom Exter, Lu Jiehua, Louis Pol, Filomena Raccioppi, Eduardo Rios-Neto and Bernard Salt.

The seminar was held on 9th-10th October 2007 in Sydney (Australia). It was attended by 25 participants from seven countries (Australia, Brazil, Canada, China, India, Indonesia and the United States). It consisted of seven sessions and a summary meeting. Nineteen papers were presented, which covered a range of issues of interest to business demography. At the conclusion of the seminar, participants were surveyed in regard to their interest in assembling the papers together in some form of publication and asked for suggestions on how this might occur. They were found to be in favor of this next step and the majority suggested having a voluntary submission with a formal review process. It was also suggested that the Panel ask the editor of Population Research and Policy Review if his journal would be interested in having a special issue dedicated to this topic. On receiving a positive response from the journal, Farhat Yusuf and David Swanson agreed to co-edit this special issue. It contains a selection of seven papers. They were reviewed by the coeditors and an international team of reviewers.

This special issue touches directly or indirectly on some of the major topics of business demography. It includes papers on consumer demographics (Yusuf and Brooks 2010), use of demographics in site selection (Beckett and Morrison 2010; Morrison and Bryan 2010), forecasting of small area populations (Swanson et al. 2010), human resource management (Clark and Ghent 2010), and demographic training of business students (Martins and Brooks 2010; Swanson and Morrison 2010).

The Scientific Panel on Business Demography wishes to acknowledge the logistical support provided by the Sydney office of the Australian Bureau of Statistics and Macquarie University, the financial support of the International Union for the Scientific Study of Population which facilitated the attendance of participants from some developing countries and various colleagues who helped in the reviewing process.

Open Access This article is distributed under the terms of the Creative Commons Attribution Noncommercial License which permits any noncommercial use, distribution, and reproduction in any medium, provided the original author(s) and source are credited.

\section{References}

Beckett, M. K., \& Morrison, P. A. (2010). Assessing the need for a new medical school: A case study in applied demography. Popul Res Policy Rev. doi:10.1007/s11113-009-9145-6.

Clark, R. L., \& Ghent, L. S. (2010). Strategic HR management with an aging workforce: Using demographic models to determine optimal employment policies. Popul Res Policy Rev. doi:10.1007/s11113009-9143-8.

Kintner, H., Merrick, T., Morrison, P., \& Voss, P. (1994). Demographics: A casebook for business and government. Boulder, Colorado: Westview Press.

Martins, J. M., \& Brooks, G. (2010). Teaching consumer demographics to marketing students. Popul Res Policy Rev. doi:10.1007/s11113-009-9146-5 
Morrison, P. A., \& Bryan, T. M. (2010). Targeting spatial clusters of elderly consumers in the U.S.A. Popul Res Policy Rev. doi:10.1007/s11113-009-9149-2.

Murdock, S., \& Ellis, D. (1991). Applied demography: An introduction to basic concepts, methods, and data. Boulder, Colorado: Westview Press.

Murdock, S., \& Swanson, D. A. (2008). Applied demography at the beginning of the 21st century, Chapter 1. In S. Murdock \& D. A. Swanson (Eds.), Applied demography in the 21st century. Dordecht, The Netherlands: Springer.

Pol, L., \& Thomas, R. (1997). Demography for business decision making. Westport, CT: Quorum Books.

Rives, N. W., \& Serow, W. (1984). Introduction to applied demography. Beverly Hills, California: Sage Publications.

Siegel, J. (2002). Applied demography: Applications to business, government, law, and public policy. San Diego: Academic Press.

Smith, S., \& Morrison, P. (2005). Small-area and business demography. In M. Micklin \& D. Poston Jr. (Eds.), Handbook of population (pp. 761-786). New York, NY: Kluwer Academic/Plenum.

Swanson, D., Burch, T., \& Tedrow, L. (1996). What is applied demography? Population Research and Policy Review, 15(5/6), 403-418.

Swanson, D. A., \& Morrison, P. A. (2010). Teaching business demography using case studies. Popul Res Policy Rev. doi:10.1007/s11113-009-9155-4.

Swanson, D., \& Pol, L. (2008). Applied demography: Its business and public sector components. In Y. Zeng (Ed.) The Encyclopedia of Life Support Systems, Demography Volume. Oxford, England: UNESCO-EOLSS Publishers (Online at http://www.eolss.net/, last accessed June, 2009).

Swanson, D. A., Schlottmann, A., \& Schmidt, B. (2010). Forecasting the population of census tracts by age and sex: An example of the Hamilton-Perry method in action. Popul Res Policy Rev. doi:10.1007/s11113-009-9144-7.

Yusuf, F., \& Brooks, G. (2010). Demographics and consumption patterns in urban China. Popul Res Policy Rev. doi:10.1007/s11113-009-9154-5. 